\title{
Bacteria with antimicrobial properties isolated from the Mediterranean sponges Chondrilla nucula and Petrosia ficiformis
}

\author{
Elisabetta Chelossi ${ }^{1, *}$, Raffaella Pantile ${ }^{2}$, Roberto Pronzato $^{2}$, Martina Milanese $^{2}$, \\ Ute Hentschel ${ }^{3}$ \\ ${ }^{1}$ Institute of Marine Sciences - Section of Marine Technologies - CNR - Via De Marini 6, 16149 Genoa, Italy \\ ${ }^{2}$ Dipartimento per lo Studio del Territorio e delle sue Risorse (DIP.TE.RIS.), University of Genoa, Corso Europa 26, \\ 16132 Genoa, Italy \\ ${ }^{3}$ Research Center for Infectious Diseases, University of Würzburg, Rontgenring 11, 97070 Würzburg, Germany
}

\begin{abstract}
Bacteria were isolated seasonally from the Mediterranean sponges Chondrilla nucula and Petrosia ficiformis and screened for antibacterial activities. Selected isolates were taxonomically identified by 16S rRNA gene sequencing. A total of 416 different bacterial strains were isolated, 60 $(14.4 \%)$ of which displayed variable degrees of antimicrobial activity. Of the bioactive strains, $58.3 \%$ were able to inhibit Staphylococcus aureus, $6.7 \%$ were active against Bacillus subtilis, $11.7 \%$ against both Enterococcus faecalis and Escherichia coli, 38.3\% against Pseudoalteromonas atlantica and $33.3 \%$ against Pseudomonas elongata. 16S rRNA gene sequence analysis showed that 2 isolates, 1 from seawater samples and 1 from $P$. ficiformis, were most closely related to Bacillus subtilis $(99 \%$ similarity) and that another isolate from $P$. ficiformis was most closely related to a previously described sponge-associated Alphaproteobacterium NW001 (98\% similarity). Two isolates from C. nucula were most closely related to Brachybacterium paraconglomeratum (99\% similarity) and Shewanella algae (89\% similarity). The high percentage of bioactive isolates derived from the 2 sponges suggests that marine microorganisms, whether animal-associated or planktonic, are promising sources for drug discovery.
\end{abstract}

KEY WORDS: Antimicrobial activity $\cdot$ Associated bacteria $\cdot$ Chondrilla nucula $\cdot$ Petrosia ficiformis Porifera $\cdot 16 \mathrm{~S}$ rRNA

\section{INTRODUCTION}

Members of the Phylum Porifera (sponges) are often associated with large microbial communities comprising autotrophic and heterotrophic bacteria. Spongeassociated microorganisms are dispersed in the intercellular mesohyl matrix or contained within specialised cells called bacteriocytes; bacterial concentrations reach 2 to 4 orders of magnitude higher than in surrounding seawater (Friedrich et al. 2001, Hentschel et al. 2003, 2006, Scheuermayer et al. 2006). Functions of sponge-associated bacteria include nutritional sup- port, skeletal support, prevention of photo-oxidation and defense against potential predators and biofouling (for a summary, see Hentschel et al. 2003 and references therein).

An increasing number of bioactive compounds originally isolated from sponges are actually produced by sponge-associated bacteria (Piel et al. 2004). As sponge-derived bioactive compounds are attracting applied scientific interest, the potential of obtaining these secondary molecules through cultivation of microorganisms offers promising solutions to the marine invertebrate supply problem. Typically, the 
compounds of interest are found only in traces and harvesting in the field poses ethical and operational constraints.

We focus here on the isolation of bacteria from 2 Mediterranean sponges. Chondrilla nucula Schmidt 1862 (Demospongiae, Chondrosida) is a thick encrusting sponge that forms large patches of interconnected clones on well-lit substrata. It occurs from the sea surface to $\sim 30 \mathrm{~m}$ depth. In addition to populations of Synechococcus (Cyanobacteria) in the light-exposed sponge surface layer, there are extracellular heterotrophic bacteria in the mesohyl matrix. The heterotrophs are sometimes enclosed within bacteriocytes (Usher et al. 2004). The bacterial community associated with $C$. nucula was recently characterized by $16 \mathrm{~S}$ rDNA-based methods (Thiel et al. 2007). Interestingly, $79 \%$ of all C. nucula-derived phylotypes were most closely related to other sponge-specific microbial lineages, which reflects the highly specific nature of the microbial community associated with marine 'bacteriosponges' (Hentschel et al. 2006). Cytotoxic and deterrent activities have been demonstrated in Mediterranean and Caribbean C. nucula specimens (see references in Milanese et al. 2003).

Petrosia ficiformis (Poiret 1789) (Demospongiae, Haplosclerida) is a massive sponge living on hard substrata to $\sim 50 \mathrm{~m}$ depth. The color of the sponge can be either dark-violet or white depending on the presence or absence of pigmented, symbiotic Synechococcus (Usher et al. 2004). Cyanobacteria symbiotic in P. ficiformis play a metabolic role and are also involved in screening excessive solar radiation (Regoli et al. 2000). Heterotrophic bacteria are present in the mesohyl and within specialised sponge-cells. The genus Petrosia is rich in bioactive compounds with cytotoxic, antibacterial and antifungal properties (e.g. Lim et al. 2001).

\section{MATERIALS AND METHODS}

Sponge samples. We collected samples at Paraggi in the Portofino Marine Protected Area (Ligurian Sea, NW Mediterranean Sea) by SCUBA diving. All Chondrilla nucula samples were obtained from a single patch at $8 \mathrm{~m}$ depth, while the Petrosia ficiformis samples were taken from a large individual at $9 \mathrm{~m}$ depth. Sponge samples of approximately $5 \mathrm{~cm}^{3}$ were cut underwater with scalpels, transferred into previously sterilised vials and transported to the laboratory in cooled bags $\left(12\right.$ to $15^{\circ} \mathrm{C}$ ). Replicates (1 l) of surrounding seawater (SW) were also collected on each sampling occasion.

Bacterial isolation. Bacteria were isolated from sponge and seawater samples collected in the period December 2002 to August 2003. Each sponge speci- men was rinsed in sterile seawater prior to further analysis. Viable heterotrophic bacteria from the surface and from the mesohyl were isolated as previously described (Chelossi et al. 2004). Epibiotic bacteria were obtained by swabbing a small area (ca. $1 \mathrm{~cm}^{2}$ ) of each sponge specimen with a sterile cotton swab, diluted in $2 \mathrm{ml}$ of filtered natural seawater (FNSW, $0.2 \mu \mathrm{m}$, Millipore) and vortexed. Mesohyl sub-samples $\left(1 \mathrm{~cm}^{3}\right)$ were cut from sponges and homogenized under sterile conditions in $4 \mathrm{ml}$ of FNSW. Homogenates were briefly centrifuged $(30 \times g, 5 \mathrm{~min})$ and the resulting supernatant fluid was used for analyses. Three $1 \mathrm{ml}$ sub-samples were taken from each 11 seawater sample (SW) and prepared as below. Serial 10-fold dilutions of each solution (sponge-supernatant and SW sub-samples) were prepared and aliquots $(0.1 \mathrm{ml})$ were plated onto marine agar (MA, Microbiol). Plates were incubated at room temperature $\left(20\right.$ to $\left.25^{\circ} \mathrm{C}\right)$ for $7 \mathrm{~d}$. Viable heterotrophic bacteria were counted as colonyforming units (CFU) on agar plates. For each sample, isolates were chosen from the widest variety of colony morphologies to increase bacterial diversity. All isolates were reisolated and subcultured. Strains were preserved in agar stabs or as lyophilised samples.

Antimicrobial screening. Sponge isolates were tested for antimicrobial activity against 6 indicator strains: Escherichia coli ATCC25922, Staphylococcus aureus ATCC25923, Pseudoalteromonas atlantica ATCC19262, Pseudomonas elongata LMG2182, Bacillus subtilis ATCC10774 and Enterococcus faecalis ATCC10741. Antimicrobial activities were screened using the spot-on-lawn method. Briefly, $100 \mu \mathrm{l}$ overnight cultures of each indicator strain were seeded as a lawn on MA plates. We spotted $10 \mu \mathrm{l}$ of overnight culture $\left(10^{8}\right.$ cells $\left.\mathrm{ml}^{-1}\right)$ from each strain onto agar plates seeded with actively growing cells of the indicator organism. Following overnight incubation (ON) at $25^{\circ} \mathrm{C}$, plates were checked for the formation of inhibition zones around spots. The zone of inhibition around the spot was measured and the assay was scored positive $(+)$ if the inhibition zone was $\leq 10 \mathrm{~mm}$, double positive (++) if between 10 and $19 \mathrm{~mm}$, triple positive (+++) if $\geq 20 \mathrm{~mm}$, and negative (-) if there was no inhibition of reference strains. The most active strains were chosen for further analysis.

16S rRNA gene sequencing and phylogenetic analysis. Genomic DNA was extracted after an overnight incubation $\left(20^{\circ} \mathrm{C}\right.$, with shaking) of each strain in $3 \mathrm{ml}$ of Marine Broth 2216 (Difco) using the modified protocol of Grimberg et al. (1989). In total, $2 \mathrm{ml}$ of ON culture were centrifuged for $4 \mathrm{~min}$ at $7741 \times g$, the pellet was washed with $1 \mathrm{ml}$ TNE buffer and spun down again. The pellet was resuspended in $270 \mu \mathrm{l}$ TNEX buffer and $25 \mu$ lysozime. After a 30 min incubation at $37^{\circ} \mathrm{C}, 50 \mu$ l Proteinase $\mathrm{K}$ were added and samples were 
incubated at $60^{\circ} \mathrm{C}$ for $2 \mathrm{~h}$. Samples were then added to $15 \mu \mathrm{NaCl}$ (5 M), and $500 \mu \mathrm{l}$ ice-cold EtOH $100 \%$ were added to samples that were then spun down for $15 \mathrm{~min}$ at $20442 \times g$, washed with $500 \mu \mathrm{l}$ of $70 \%$ EtOH and air dried. DNA was resuspended in $200 \mu \mathrm{l}$ of sterile water. The universal primers $27 \mathrm{f}$ and $1492 \mathrm{r}$ were used for $16 \mathrm{~S}$ rRNA gene amplification. PCR amplification was performed using a Mastercycler Gradient (Eppendorf) as follows: one initial denaturation step for $10 \mathrm{~min}$ at $94^{\circ} \mathrm{C} ; 30$ cycles of $1 \mathrm{~min}$ at $94^{\circ} \mathrm{C}, 1 \mathrm{~min}$ at $54^{\circ} \mathrm{C}, 1.5 \mathrm{~min}$ at $72^{\circ} \mathrm{C}$; one final elongation step for $10 \mathrm{~min}$ at $72^{\circ} \mathrm{C}$. The PCR mix consisted of $5 \mu$ of $10 \times$ reaction buffer (Qiagen), $1 \mu \mathrm{l}(2 \mathrm{mM})$ of each primer, $1 \mu \mathrm{l}(0.2 \mathrm{mM})$ of dNTPs, $0.25 \mu \mathrm{l}(1.25 \mathrm{U})$ of Taq DNA polymerase (Qiagen), $1 \mu \mathrm{l}$ of DNA template and distilled water to reach a final volume of $50 \mu \mathrm{l}$. A total of $10 \mu \mathrm{l}$ of each PCR product were checked by electrophoresis (run for $30 \mathrm{~min}$ at $300 \mathrm{~V}$ on a $1 \%$ agarose gel). PCR products were purified with the Qiagen PCR purification kit (Qiagen) according to the manufacturer's protocol. Purified amplification products were subjected to sequencing PCR reactions using the universal primers $27 \mathrm{f}$ or $1492 \mathrm{r}$ and the reaction kit BigDye Terminator Cycle Sequencing Ready Reaction (Applied Biosystems). The products were further purified using ABI Prism sequencing reagents and protocol. Sequencing was performed on an ABI Prism 310 Genetic Analyzer (Perkin-Elmer). The sequences were aligned to nearly full length 16S rRNA gene contigs using the ABI Prism software (Perkin-Elmer) and compared to 16S rRNA genes in the GenBank database using the BLASTN search algorithm (www.ncbi.nlm.nih.gov/BLAST/).

\section{RESULTS}

Viable counts of the heterotrophic bacterial communities associated with the surface and mesohyl of Chondrilla nucula and Petrosia ficiformis and from ambient seawater are given in Table 1. Viable counts were largely consistent over sampling times. A weak positive trend was noted for $C$. nucula from winter to summer. Viable counts from mesohyl were about one order of magnitude higher than those for the surface which were in turn one to 2 orders of magnitude higher than those from ambient seawater. A total of 416 bacterial strains was isolated from colonies with different phenotypic characteristics. Sixty strains $(14.4 \%$ of isolates) displayed antibacterial activity against one or more reference strains. Of these, $58.3 \%$ were active against Staphylococcus aureus, $6.7 \%$

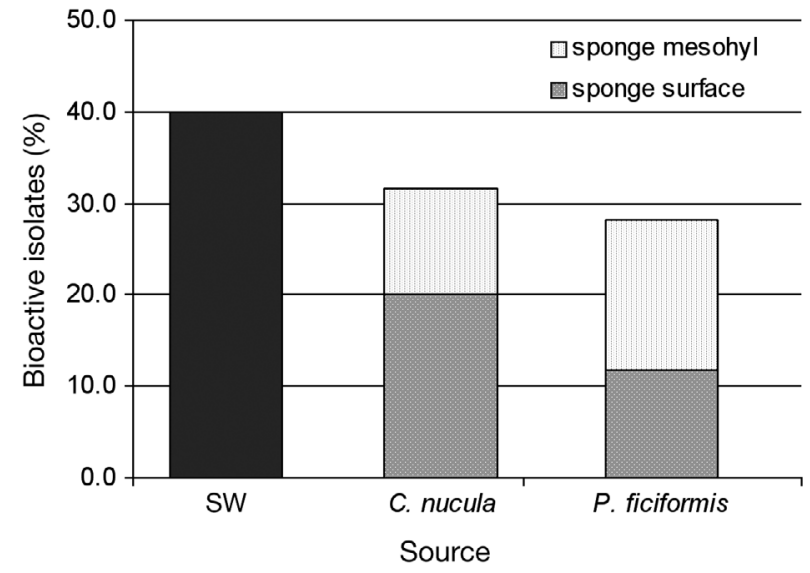

Fig. 1. Percentage of bioactive isolate recovered from sponge tissues (mesohyl, surface) and seawater (SW). C. = Chondrilla, $P=$ Petrosia

against Bacillus subtilis, $11.7 \%$ against Enterococcus faecalis, $11.7 \%$ against Escherichia coli, 38.3\% against Pseudoalteromonas atlantica and $33.3 \%$ against Pseudomonas elongata (Table 2). Forty percent of the bioactive strains were isolated from seawater, $31.7 \%$ from $C$. nucula and $28.3 \%$ from $P$. ficiformis. In $C$. nucula, $63.2 \%$ and $36.8 \%$ of bioactive isolates were from the surface and mesohyl, respectively $(36.8 \%)$; in $P$. ficiformis, $41.2 \%$ and $58.8 \%$ were from the surface and mesohyl, respectively (Fig. 1). No bioactive strains were isolated in December 2002; $13.3 \%$ of the total number of bioactive isolates across all months $(n=60)$ were isolated in January and in March 2003, 28.3\% in June 2003 and 45.5\% in August 2003 (Fig. 2). Of the total number of January isolates (bioactive + nonbioactive), $12.3 \%$ were bioactive; the respective frequency in March was $8.9 \%, 11.3 \%$ in June and $34.2 \%$ in August 2003 (Fig. 2). Fig. 2 also shows the relative contributions in each month of sponges and seawater as a proportion ( $\%$ ) of total number of bioactive isolates across all dates $(n=60)$ and as a percentage of total isolates in each month. There was a seasonal trend from
Table 1. Viable counts of heterotrophic bacteria (as CFU $\times 10^{3} \mathrm{~cm}^{-2}$ on marine agar medium $;$ CFU = colony-forming units) associated with the surface and the mesohyl of Chondrilla nucula and Petrosia ficiformis and derived from seawater. Units are expressed as means (SE) $\mathrm{n}=6 ; \mathrm{nd}=$ not determined

\begin{tabular}{|lccccc|}
\hline \multirow{2}{*}{$\begin{array}{l}\text { Sampling } \\
\text { period }\end{array}$} & Seawater & \multicolumn{2}{c}{ Chondrilla nucula } & \multicolumn{2}{c|}{ Petrosia ficiformis } \\
& & Surface & Mesohyl & Surface & Mesohyl \\
\hline Dec 2002 & $0.3(0.1)$ & $0.2(0.1)$ & $40(2.7)$ & nd & $35(3.9)$ \\
Jan 2003 & $0.48(0.12)$ & $2.6(0.3)$ & $49(3.2)$ & $102(18)$ & $6300(250)$ \\
Ma. 2003 & $5.3(1.7)$ & $50(8.2)$ & $240(3.7)$ & $15(2.3)$ & $370(38)$ \\
Jun 2003 & $0.74(0.12)$ & $17(2.0)$ & $270(21)$ & $150(21)$ & $3800(340)$ \\
Aug 2003 & $0.39(0.06)$ & $54(13)$ & $790(65)$ & $62(3.7)$ & $830(98)$ \\
\hline
\end{tabular}


Table 2. Antimicrobial activities of sponge and seawater isolates. S. aur: Staphylococcus aureus; B. sub: Bacillus subtilis; E. fae: Enterococcus faecalis; E. coli: Escherichia coli; P. alt: Pseudoalteromonas atlantica; P. elong: Pseudomonas elongata. Bold: isolates whose 16S rRNA gene was sequenced. Percentage inhibition refers to the total of 60 bioactive isolates.,+++ and $+++=$ inhibition zones $\leq 10,10$ to 19 and $\geq 20 \mathrm{~mm}$, respectively; $-=$ no inhibition

\begin{tabular}{|c|c|c|c|c|c|c|c|}
\hline $\begin{array}{l}\text { Sample } \\
\text { date }\end{array}$ & Isolate & $\begin{array}{c}S . \\
\text { aur }\end{array}$ & $\begin{array}{c}B . \\
\text { sub }\end{array}$ & $\begin{array}{l}E . \\
\text { fae }\end{array}$ & $\begin{array}{c}E . \\
\text { Coli }\end{array}$ & $\begin{array}{l}P . \\
\text { atl }\end{array}$ & $\begin{array}{c}P . \\
\text { elong }\end{array}$ \\
\hline \multirow[t]{8}{*}{ Jan 2003} & CH37 & +++ & - & - & - & - & + \\
\hline & PA7 & ++ & - & - & - & +++ & +++ \\
\hline & PB7 & - & - & - & - & + & - \\
\hline & AD3 & _- & - & _- & - & - & + \\
\hline & $\mathrm{AD} 4$ & - & - & - & - & - & ++ \\
\hline & AD9 & - & - & - & - & - & ++ \\
\hline & AD17 & - & - & - & - & + & - \\
\hline & AE14 & - & - & - & - & - & + \\
\hline \multirow[t]{8}{*}{ Mar 2003} & РТВ9 & ++ & - & - & + & + & - \\
\hline & PTB16 & - & - & - & - & - & + \\
\hline & TCA1 & - & - & - & - & + & - \\
\hline & TCA8 & + & - & +++ & + & + & +++ \\
\hline & SWA3 & - & - & - & - & ++ & - \\
\hline & SWA12 & + & - & +++ & + & - & +++ \\
\hline & SWC11 & - & - & + & - & + & +++ \\
\hline & TCC2 & - & - & - & - & + & - \\
\hline \multirow[t]{17}{*}{ Jun 2003} & SWB1 & + & + & ++ & - & + & + \\
\hline & SWB2 & +++ & + & - & - & - & - \\
\hline & SWB3 & + & - & - & - & - & - \\
\hline & SWB6 & - & - & - & - & - & + \\
\hline & SWB7 & - & - & - & - & - & ++ \\
\hline & SWB11 & + & - & - & - & - & ++ \\
\hline & SWB12 & ++ & - & - & - & - & - \\
\hline & SWB14 & + & - & - & - & - & - \\
\hline & SWB15 & - & - & - & - & + & - \\
\hline & SWB16 & ++ & - & - & - & - & + \\
\hline & SWA4 & ++ & - & - & - & - & - \\
\hline & SWA7 & - & - & - & - & ++ & - \\
\hline & PA3 & +++ & - & - & - & + & - \\
\hline & PC10 & - & - & - & - & - & + \\
\hline & $\mathrm{TCC} 4$ & - & - & - & - & ++ & - \\
\hline & TCC5 & - & - & - & - & ++ & - \\
\hline & TCC6 & - & - & - & - & ++ & - \\
\hline \multirow[t]{28}{*}{ Aug 2003} & SWA3 & +++ & - & - & - & - & - \\
\hline & SWA4 & +++ & - & - & - & + & - \\
\hline & SWA7 & + & - & - & - & - & - \\
\hline & SWA11 & +++ & - & - & - & - & - \\
\hline & TPA2 & - & - & + & - & - & - \\
\hline & TPA4 & +++ & - & - & + & - & - \\
\hline & TPA5 & +++ & - & - & - & - & - \\
\hline & TPA6 & +++ & - & - & - & - & - \\
\hline & TPA7 & +++ & - & - & + & + & - \\
\hline & PA1 & + & - & - & - & - & + \\
\hline & PA3 & - & - & - & - & + & - \\
\hline & $\mathrm{PC} 2$ & ++ & - & - & - & - & - \\
\hline & PC3 & ++ & + & - & - & - & - \\
\hline & PC4 & +++ & - & - & ++ & + & - \\
\hline & PC6 & - & + & - & - & - & - \\
\hline & TCA1 & +++ & - & + & - & ++ & - \\
\hline & TCA3 & ++ & - & - & - & - & - \\
\hline & TCA5 & - & - & + & - & - & - \\
\hline & $\mathrm{TCC} 1$ & ++ & _- & - & - & _- & - \\
\hline & TCC2 & - & - & - & - & - & + \\
\hline & TCC3 & - & - & - & - & - & + \\
\hline & CHB1 & ++ & - & - & + & + & - \\
\hline & CHB2 & +++ & - & - & - & - & - \\
\hline & $\mathrm{CHC1}$ & +++ & - & - & - & - & - \\
\hline & CHC2 & +++ & - & - & - & + & + \\
\hline & $\mathrm{CHC} 3$ & ++ & - & - & - & - & - \\
\hline & CHC8 & +++ & - & - & - & ++ & + \\
\hline & $\%$ inhibition & 58.3 & 6.7 & 11.7 & 11.7 & 38.3 & 33.3 \\
\hline
\end{tabular}

winter to summer of increasing relative sponge contribution to the number of bioactive isolates.

Of the bioactive strains from sponge and seawater samples, $23.3 \%$ and $11.7 \%$, respectively, inhibited $\geq 3$ test strains of bacteria. Partial 16S rDNA sequences of 5 selected bioactive isolates were obtained and compared to known database entries in GenBank. The sequences of 2 Gram-positive, spore-forming rods (strains PA7 and SWA12) were most closely related to that of Bacillus subtilis (99\%) (Table 3). The 16S rRNA gene sequence of strain $\mathrm{CHC} 2$ was $89 \%$ similar to both the marine Gram-negative bacterium Shewanella algae and to an uncultured bacterial clone. Strain PC4 was most closely related (98\% similarity) to the culturable Alphaproteobacterium strain NW001 that seems to be specifically associated with at least 8 different marine sponges (Scheuermayer et al. 2006) and with sponge larvae (Enticknap et al. 2006). The 16S rDNA sequence of strain $\mathrm{CHC} 8$ was most similar $(99 \%)$ to Brachybacterium paraconglomeratum (Actinobacteria) (Table 3).

\section{DISCUSSION}

We focused on recovery and seasonal variation of bioactive bacterial isolates associated with the Mediterranean sponges Chondrilla nucula and Petrosia ficiformis. In culture, there was a 2 order of magnitude difference between the heterotrophic microbial communities from the mesohyl of 2 sponges and those from ambient seawater (Table 1), in accordance with previous work in temperate areas (Friedrich et al. 2001). Furthermore, surface bacterial densities were approximately one order of magnitude lower than those in the sponge mesohyl (Table 1), as previously shown for P. ficiformis (Chelossi et al. 2004). Because a single large $P$. ficiformis specimen and the same large $C$. nucula patch were repeatedly sampled over time, no information can be 


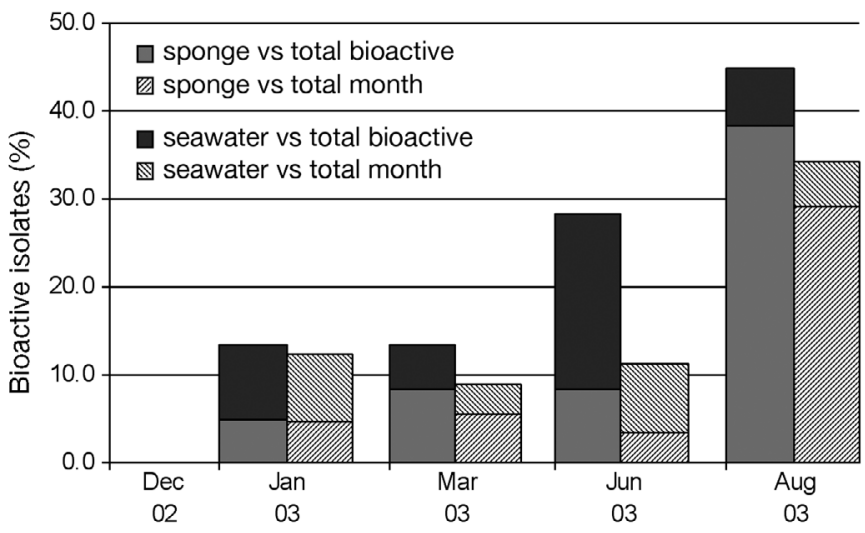

Fig. 2. Recovery of bioactive bacteria over time. Total number of bioactive samples (n) across all dates was 60. Solid bars indicate the percentage of total bioactive isolates (60) found in each month, with relative contributions from sponges (grey) and seawater (black). Cross-hatched bars show the percentage at each collection time of bioactive isolates as a proportion of total monthly isolates (bioactive + non-bioactive: December 2002, $\mathrm{N}=32$; January 2003, $\mathrm{N}=65$; March 2003, $\mathrm{N}=90$; June 2003, $\mathrm{N}=150$; August 2003, $\mathrm{N}=79$, grand total = 416). Cross-hatched bars are divided to show relative contributions of bioactive bacteria isolated from sponges and seawater as percentage of total isolates in each month

gained about intra-individual variation. CFU of total isolates are slightly lower than CFU titres from 10 different Mediterranean sponges including C. nucula and P. ficiformis (Muscholl-Silberhorn et al. 2007).

Of 416 heterotrophic strains isolated, $14.4 \%$ were able to inhibit at least one reference strain. This number is strikingly congruent with that of Muscholl-Silberhorn et al. (2007) who found that $15.2 \%$ of all subcultured colonies were active against at least 1 test strain. Almost $60 \%$ of bioactive isolates we retrieved were active against Staphylococcus aureus, which opens interesting avenues in the search for novel compounds against multidrug-resistant pathogenic staphylococci. The high frequency of activity against
Gram-negative bacteria is intriguing. In a comparable study, the Gram-negative test bacterium Escherichia coli was inhibited by $>75 \%$ of bioactive isolates from sponges (Muscholl-Silberhorn et al. 2007). In our study however, the Gram-negative bacteria Pseudoalteromonas atlantica (38.3\% inhibition) and Pseudomonas elongata (33.3\% inhibition) were more susceptible than E. coli (11.7\% inhibition) (Table 2). Gram-negative bacteria are generally less susceptible to antimicrobials than Gram-positive bacteria because of the presence of an outer membrane and LPS (lipopolysaccharide) which together act as an efficient barrier against hydrophobic and lipophilic molecules. Among Gram-negative bacteria, Pseudomonas species are generally more resistant to antibiotic drugs than other genera. Although P. elongata strain LMG2182 used in our screening is more closely related to the genus Microbulbifer than to authentic pseudomonads (Yoon et al. 2003), it is intrinsically resistant to betalactam antibiotics and yet inhibited by a large percentage of our isolates.

Surprisingly, a large fraction of bioactive isolates was retrieved from seawater (Fig. 1), indicating that the water column microbial community can be considered a suitable source for novel antimicrobial compounds. Bioactive bacteria have been identified previously in seawater samples at numbers that are well within the range of those reported for sponges (e.g. MuschollSilberhorn et al. 2007). The benefits of anti-infective substances for the producing microbe in the seawater environment are not clear. It appears that competition among microbes may also occur in seawater, for example during settlement of the bacteria on particles such as detritus or marine snow.

About one-third of the bioactive isolates were recovered from each of Chondrilla nucula and Petrosia ficiformis (Fig. 1), consistent with reports by Chelossi et al. (2004) yet contrasting with results of MuschollSilberhorn et al. (2007), who did not recover bioactive

Table 3. 16S rRNA gene sequence analysis of 5 selected bioactive isolates. $C .=$ Chondrilla,$P .=$ Petrosia

\begin{tabular}{|c|c|c|c|c|c|c|}
\hline Isolate & Source & $\begin{array}{l}\text { GenBank } \\
\text { accession no. }\end{array}$ & Closest match in GenBank & $\begin{array}{l}\text { Accession } \\
\text { no. }\end{array}$ & $\begin{array}{l}\text { Identity } \\
(\%)\end{array}$ & $\begin{array}{l}\text { Phylogenetic } \\
\text { affiliation }\end{array}$ \\
\hline PA7 & $\begin{array}{l}\text { P. ficiformis } \\
\text { mesohyl }\end{array}$ & EF192100 & Bacillus subtilis strain ZJUT & EF694950 & 99 & $\begin{array}{l}\text { Firmicutes, } \\
\text { Bacillaceae }\end{array}$ \\
\hline $\mathrm{PC} 4$ & $\begin{array}{l}\text { P. ficiformis } \\
\text { mesohyl }\end{array}$ & EF192102 & $\begin{array}{l}\text { Great Barrier Reef sponge-associated } \\
\text { Alphaproteobacterium strain NW001 }\end{array}$ & AF295099 & 98 & Alphaproteobacteria \\
\hline $\mathrm{CHC} 2$ & $\begin{array}{l}\text { C. nucula } \\
\text { mesohyl }\end{array}$ & EF202836 & $\begin{array}{l}\text { Uncultured bacteria clone ctg NISAA41, } \\
\text { Shewanella algae strain YJ06114 }\end{array}$ & $\begin{array}{l}\text { DQ396218, } \\
\text { EF542799 }\end{array}$ & 89 & $\begin{array}{l}\text { Gammaproteobacteria } \\
\text { Alteromonadaceae }\end{array}$ \\
\hline $\mathrm{CHC} 8$ & $\begin{array}{l}\text { C. nucula } \\
\text { mesohyl }\end{array}$ & EF192098 & $\begin{array}{l}\text { Brachybacterium paraconglomeratum } \\
\text { strain LMG 19861T from deteriorated } \\
\text { parts of a medieval wall painting }\end{array}$ & AJ415377 & 99 & $\begin{array}{l}\text { Actinobacteria, } \\
\text { Dermabacteraceae }\end{array}$ \\
\hline SWA12 & Seawater & EF081005 & $\begin{array}{l}\text { Bacillus subtilis strain JKC-13 from } \\
\text { Korean fermented food }\end{array}$ & EF517121 & 99 & $\begin{array}{l}\text { Firmicutes, } \\
\text { Bacillaceae }\end{array}$ \\
\hline
\end{tabular}


bacteria from these 2 sponge species. We found that about half of the sponge bioactive strains were derived from the sponge surfaces. The role of surface bacteria in the control of fouling has been already elucidated for marine algae and invertebrates including sponges (Lee \& Quian 2004), but only few studies have investigated the microbial composition of sponge surfaces and their role in chemical defense (e.g. Chelossi et al. 2004, Thakur et al. 2004).

The number of bioactive isolates increased from winter to summer (Fig. 2) apparently due to an increased general diversity rather than to one of few dominant bioactive strains. The contribution of bioactive strains by sponges (relative to seawater) tended to increase concomitantly. These results suggest that the warmer seasons might increase competitive interactions between bacteria, which in turn may lead to a predominance of bacteria able to produce bioactive compounds. In fact, invertebrate diseases in the Mediterranean Sea resulting from opportunistic/pathogenic bacteria usually break out at the end of the summer season (Gaino \& Pronzato 1989, Cerrano et al. 2000). Mass mortality events related to the presence of invasive bacteria have been recorded in the recent decades for Mediterranean sponge populations (Gaino \& Pronzato 1989).

Sequencing of isolates that inhibited $\geq 3$ reference strains revealed their affiliation with the genera Bacillus, Brachybacterium, Shewanella and Alphaprotebacteria (Table 3). Marine Bacillus species are usually isolated from sediments including mud and some strains have been found in association with marine sponges (Thakur et al. 2004, Muscholl-Silberhorn et al. 2007). Most Bacillus strains are able to produce peptidic compounds with antibacterial activity (e.g. Jaruchoktaweechai et al. 2000). The genus Brachybacterium comprises Gram-positive coryneform bacteria with high $\mathrm{G}+\mathrm{C}$ contents. This genus and related species are common in soil, but have also been cultivated from marine sediments. Recently, Actinobacteria (belonging to the genus Brachybacterium) strains have also been cultured from marine sponges (Montalvo et al. 2005). Antimicrobially active strains of this genus have not been found before. The genus Shewanella comprises Gram-negative, facultative anaerobic bacteria belonging to the Gammaproteobacteria. Marine Shewanella strains are known to produce bioactive compounds, and a new species has been recently isolated from Mediterranean sponges (Lee et al. 2006).

The Alphaproteobacterium strain PC4 belongs to the previously described, apparently sponge-specific clade of Alphaproteobacterium MBIC 3368 and related strains (Thiel \& Imhoff 2003, Enticknap et al. 2006, Scheuermayer et al. 2006 and references cited therein, Muscholl-Silberhorn et al. 2007). This clade is closely related to Pseudovibrio denitrificans, which is a novel taxon of heterotrophic and facultative anaerobes (Shieh et al. 2004). Antimicrobial activity has been demonstrated for at least 2 Alphaproteobacterium MBIC3368-related isolates from marine sponges (Thiel \& Imhoff 2003, Hentschel et al. 2006). Retrieving the closely related, bioactive isolate PC4 from Petrosia ficiformis further supports the hypothesis that sponges provide a microhabitat for specific microorganisms. To our knowledge, neither of the strains isolated and sequenced from Chondrilla nucula mesohyl (CHC2 and $\mathrm{CHC}$ ) has a close match with any of the spongederived uncultured bacterial clones sequenced by other authors and reported in GenBank. Whether the bioactivity of these isolates plays a functional role in the chemical defence of the sponge host will be subject to further investigations.

\section{CONCLUSIONS}

In the present work, 60 of 416 bacterial strains isolated from 2 Mediterranean sponges and ambient seawater had antimicrobial activities against bacterial strains that are potential pathogens for humans and animals. These antimicrobial characteristics offer relevant opportunities for applied sciences. The observed intra-individual variability, the high fraction of seawater bioactive isolates and the seasonal trend of antimicrobial-producing bacteria might indicate that the bioactive strains are rather transiently associated with the sponge from which they were isolated. Whether Petrosia ficiformis and Chondrilla nucula may rely additionally on stably-associated bioactive bacterial symbionts for defense is still an open question. Further long-time observations of marine sponge-associated microbial communities should be undertaken to better define their role in sponge ecology, symbiosis and with respect to seasonal trends.

Acknowledgements. We are particularly grateful to C. Gernert, S. Schmitt and M. Wehrl (all University of Würzburg), who helped in laboratory operations. This research was supported by the Italian Ministry for Agriculture (Grant no. 6C90) and by a personal grant from the University of Genoa to R.P. for student travel. We were also supported by a grant (bmbf BIOTECmarin: 03F0414E) to U.H. Travel by R.P. to Würzburg was made possible by DFG SFB567. All the experiments reported herein comply with the current laws of the country in which they were performed.

\section{LITERATURE CITED}

Cerrano C, Bavestrello G, Nike-Bianchi C, Cattaneo-Vietti R and 8 others (2000) A catastrophic mass-mortality episode of gorgonians and other organisms in the Ligurian Sea 
(North-western Mediterranean Sea), in summer 1999. Ecol Lett 3:284-293

Chelossi E, Milanese M, Milano A, Pronzato R, Riccardi G (2004) Characterisation and antimicrobial activity of epibiotic bacteria from Petrosia ficiformis (Porifera, Demospongiae). J Exp Mar Biol Ecol 309:21-33

Enticknap JJ, Kelly M, Peraud O, Hill RT (2006) Characterization of a culturable alphaproteobacterial symbiont common to many marine sponges and evidence for vertical transmission via sponge larvae. Appl Environ Microbiol 72:3724-3732

Friedrich AB, Fischer I, Proksch P, Hacker J, Hentschel U (2001) Temporal variation of the microbial community associated with the Mediterranean sponge Aplysina aerophoba. FEMS Microbiol Ecol 38:105-113

Gaino E, Pronzato R (1989) Ultrastructural evidence of bacterial damage to Spongia officinalis fibres (Porifera, Demospongiae). Dis Aquat Org 6:67-74

Grimberg, J, Maguire S, Belluscio L (1989) A simple method for the preparation of plasmid and chromosomal E. coli DNA. Nucleic Acids Res 17:8893

Hentschel U, Fieseler L, Wehrl M, Gernert C, Steinert M, Hacker J, Horn M (2003) Microbial diversity of marine sponges. Prog Mol Subcell Biol 37:59-88

Hentschel U, Usher KM, Taylor MW (2006) Marine sponges as microbial fermenters. FEMS Microbiol Ecol 55: 167-177

Jaruchoktaweechai C, Suwanborirux K, Tanasupawatt S, Kittakoop P, Menasveta P (2000) New macrolactins from a marine Bacillus sp. Sc026. J Nat Prod 63:984-986

Lee OO, Qian PY (2004) Potential control of bacterial epibiosis on the surface of the sponge Mycale adhaerens. Aquat Microb Ecol 34:11-21

Lee OO, Lau SCK, Tsoi MMY, Li X and 6 others (2006) Shewanella irciniae sp. nov., a novel member of the family Shewanellaceae, isolated from the marine sponge Ircinia dendroides in the Bay of Villefranche, Mediterranean Sea. Int J Syst Evol Microbiol 56:2871-2877

Lim YJ, Lee CO, Hong J, Kim DK, Im KS, Jung JH (2001) Cytotoxic polyacetylenic alcohols from the marine sponge Petrosia species. J Nat Prod 64:1565-1567

Milanese M, Chelossi E, Manconi R, Sará A, Sidri M, Pronzato R (2003) The marine sponge Chondrilla nucula Schmidt, 1862 as an elective candidate for bioremediation in integrated aquaculture. Biomol Eng 20:363-368

Editorial responsibility: Jed Fuhrman,

Los Angeles, California, USA
Montalvo NF, Mohamed NM, Enticknap JJ, Hill RT (2005) Novel actinobacteria from marine sponges. Anton Leeuwenhoek Int J G 87:29-36

Muscholl-Silberhorn A, Thiel V, Imhoff JF (2007) Abundance and bioactivity of cultured sponge-associated bacteria from the Mediterranean Sea. Microb Ecol doi: 10.1007/ s00248-007-9255-9

Piel J, Hui D, Wen G, Butzke D, Platzer M, Fusetani N, Matsunaga $S$ (2004) Antitumor poliketide biosynthesis by an uncultivated bacterial symbionts of the marine sponge Theonella swinhoei. Proc Natl Acad Sci USA 101: 16222-16227

Regoli F, Cerrano C, Chierici E, Bompadre S (2000) Susceptibility to oxidative stress of the Mediterranean demosponge Petrosia ficiformis: role of endosymbionts and solar irradiance. Mar Biol 137:453-461

Scheuermayer M, Pimentel-Elardo S, Fieseler L, Grozdanov L, Hentschel U (2006) Microorganisms of sponges: phylogenetic diversity and biotechnological potential. In: Proksch P, Müller WEG (eds) Frontiers in marine natural biotechnology. Horizon Press, London, p 289-312

Shieh WY, Lin YT, Jean WD (2004) Pseudovibrio denitrificans gen. nov., sp. nov., a marine, facultatively anaerobic, fermentative bacterium capable of denitrification. Int J Syst Evol Microbiol 54:2307-2312

Thakur NL, Anil AC, Müller WEG (2004) Culturable epibacteria of the marine sponge Ircinia fusca: temporal variations and their possible role in the epibacterial defense of the host. Aquat Microb Ecol 37:295-304

Thiel V, Imhoff JF (2003) Phylogenetic identification of bacteria with antimicrobial activities isolated from Mediterranean sponges. Biomol Eng 20:421-423

Thiel V, Leininger S, Schmaljohann R, Brummer F, Imhoff JF (2007) Sponge-specific bacterial associations of the Mediterranean sponge Chondrilla nucula (Demospongiae, Tetractinomorpha). Microb Ecol doi: 10.1007/s00 248-006-9177-y

Usher KM, Fromont J, Sutton DC, Toze S (2004) The biogeography and phylogeny of unicellular cyanobacterial symbionts in sponges from Australia and the Mediterranean. Microb Ecol 48:167-177

Yoon JH, Kim H, Kang KH, Oh TK, Park YH (2003) Transfer of Pseudomonas elongata Humm 1946 to the genus Microbulbifer as Microbulbifer elongatus comb. nov. Int J Syst Evol Microbiol 53:1357-1361

Submitted: January 3, 2007; Accepted: August 20, 2007

Proofs received from author(s): October 20, 2007 